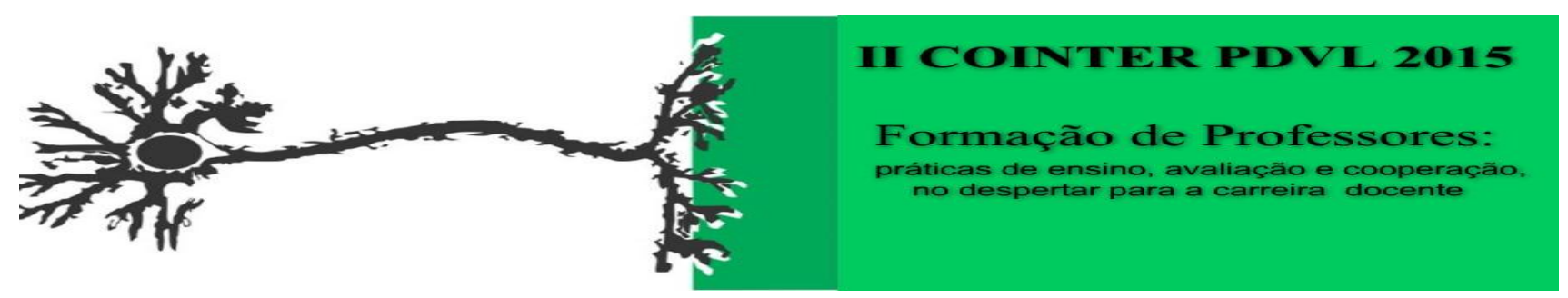

\title{
O ESTÁGIO SUPERVISIONADO E A FORMAÇÃO DA IDENTIDADE DOCENTE DE LICENCIANDOS EM QUÍMICA
}

\author{
Apresentação: Relato de Experiência \\ Elié Paula Predi Dornelas de Souza ${ }^{1}$; Jaqueline Quintino da Silva ${ }^{2}$; Johnnatan Duarte de \\ Freitas $^{3}$
}

\section{Introdução}

A compreensão do ambiente escolar para os futuros licenciados em Química do Instituto Federal de Alagoas - IFAL, é de fundamental importância para o desenvolvimento da profissão. Com isso, o estágio supervisionado II apresenta-se como um processo de inserção do estudante de licenciatura no contexto escolar. Momento no qual serão estabelecidas a relação teoria-prática, para a construção da identidade docente, através da reflexão sobre o exercício da docência. Segundo Libâneo (2002), a percepção do papel do professor como, organizar e selecionar conteúdos, programar tarefas, criar condições de aprendizagem dentro da classe, incentiva os alunos a aprender, de maneira onde o professor administra as atividades a fim de que estes tornem-se sujeitos ativos da própria aprendizagem.

\section{Relato de Experiência}

O momento da regência propicia o planejamento das aulas, este é o momento de criar condições para aproximar o aluno da ciência, inclusive para os estudantes de Licenciatura em Química, Logo, o estágio viabiliza aos futuros professores a apropriação e reflexão da complexidade das práticas educacionais em que eles irão se deparar no futuro, bem como as implicações no preparo das ações educativas desses profissionais (PIMENTA; LIMA, 2006, p. 12).

A vivência relatada ocorre numa escola estadual de Maceió, durante uma aula de físicoquímica realizada com uma proposta experimental. Esta abordava os conceitos de solubilidade, tendo como este momento a oportunidade dos licenciandos assumirem a postura de professor mediador do conhecimento utilizando como ferramenta didática a experimentação. Assim,

\footnotetext{
${ }^{1}$ Licenciatura em Química, Instituto Federal de Alagoas, eliepaulap@gmail.com

${ }^{2}$ Licenciatura em Química, Instituto Federal e Alagoas, jaqueline.quintino6@gmail.com

${ }^{3}$ Doutor em Química, Instituto Federal de Alagoas, johnnatandf@gmail.com
} 
colocando em prática os conceitos absorvidos durante o curso de licenciatura, tais como, teorias de aprendizagem e específicas da Química. Ao trabalhar os conteúdos de solubilidade, os graduandos veem a amplitude didática do conhecimento químico através dos experimentos. Nessa perspectiva, "Os conhecimentos difundidos no ensino da Química permitem a construção de uma visão de mundo mais articulada e menos fragmentada, contribuindo para que o indivíduo se veja como participante de um mundo em constante transformação."(PCNEM, 2000, p. 32).

Imagem 1: Prática experimental de Solubilidade. Fonte: Própria

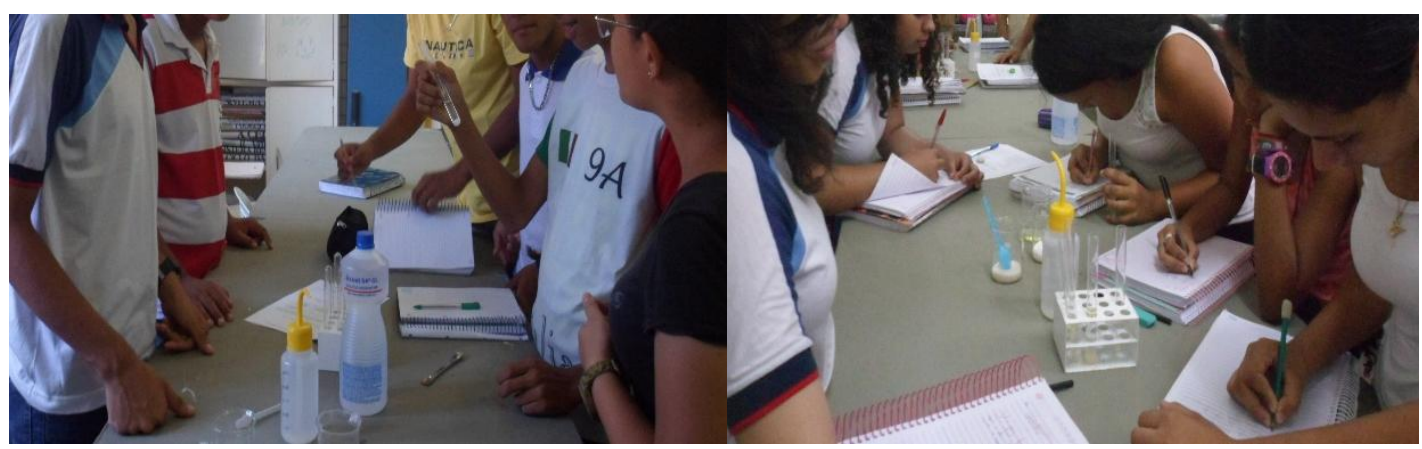

\section{Considerações}

Essa perspectiva de ensino ressalta a relevância da Didática, na qual compõe o currículo dos cursos de Licenciatura. A formação da identidade docente é otimizada através da realização do estágio de regência, bem como a prática de pesquisa no estágio.

\section{Referências}

BRASIL. MINISTÉRIO DA EDUCAÇÃO. SECRETARIA DE EDUCAÇÃO BÁSICA. Parâmetros nacionais curriculares nacionais. Ministério da Educação. Secretaria de Educação Média e Tecnológica: Brasília (DF), 2000. Parte 3.

LIBÂNEO, J. C. Didática: velhos e novos temas. Goiânia: Edição do Autor, 2002.

PIMENTA, S. G.; LIMA, M. S. L. Estágio: diferentes concepções. In: Estágio e docência. São Paulo: Cortez, 2008, p. 33-57. 